\title{
Cikkismertetés: Magas részvételi hajlandóság, magas halálozási arány?
}

\author{
Article review: Higher willingness of participation, higher mortality
}

Ismertető: $\quad$ Devosa Iván $₫$

Neumann János Egyetem, Pedagógusképző Kar, Egészségtudományi és

Egészségfejlesztési Kutatócsoport

Ismertetett cikk: Bender AM, Jørgensen T, Pisinger C. Higher mortality in women living in high-participation areas of a population-based health check and lifestyle intervention study.Int. J. Public Health., 2019;64(1):107-114. doi: 10.1007/s00038-018-1179-2.

Beküldve: $\quad$ 2019. 05. 28.

doi: $\quad$ 10.24365/ef.v60i5.476

Kulcsszavak: daganat; egészségellenőrzés; életmódbeli beavatkozás; halálozás; részvételi arány

Keywords: cancer; health check; lifestyle intervention; mortality; participation rate

\section{HÁTTÉR}

A kutatás eredeti célja a népességalapú egészségügyi vizsgálatok, illetve az életmódbeli beavatkozással járó kutatások hatékonysági mutatóinak összevetése volt a részvételi arány alapján. A dán „Inter99” randomizált vizsgálatban megkérdezett személyek alacsony, közepes és magas részvételi hajlandóságú csoportjaiban a betegségspecifikus halálozások eltérését vetették össze a férfiak és nők között. Végső soron a célkitűzés annak elemzése volt, hogy a magasabb halálozási kockázatra vonatkozó korábbi eredményeket magyarázza-e a kutatás során alkalmazott életmódbeli intervenció káros hatása, vagy az pusztán a véletlen műve.

\section{MÓDSZER}

A dániai Koppenhága megye 73 járásában élő valamennyi személyt bevonták az "Inter99” randomizált vizsgálatba 1999-ben ( $n=11483$; kontrollcsoport $n=47122$ ). Az intervenciós csoportba tartozó, iszkémiás szívbetegségekre magas kockázati besorolású egyének csoportja egészségügyi ellenőrző vizsgálaton és életvezetési tanácsadáson vett részt. Ezután a területeket felosztották az egészségügyi ellenőrzéseken mutatott részvételi hajlandóság szerint alacsony (35-49\% -os), közepes (50-54\%-os) és magas ( $\geq 55 \%$-os) kategóriákba. 10 éven keresztül rögzítették a kutatók minden személynél az elhalálozás okait.

\section{EREDMÉNYEK}

A magas részvételi aránnyal bíró területeken jelentősen magasabb volt az életmódhoz köthető halálozás kockázata, illetve a daganatos megbetegedésekhez kapcsolódó halálesetek száma az intervenciós csoportban élő nők körében, mint a kontrollcsoportnál. A dohányzással összefüggésbe hozható daganatos megbetegedésekhez kapcsolódó haláleseteknél a különbségek még hangsúlyosabbak voltak. A férfiak között nem tapasztaltak a kutatók szignifikáns eltéréseket a halandóságban a kontrollés az intervenciós csoportok között. 
Ez felvetette azt a kérdést, hogy miért volt magasabb a halálozás az intervenciós csoportban lévő nők körében a magas részvételi aránnyal bíró területeken? A halálesetek kockázatának összehasonlítása bizonyos szemszögből megvilágítja a betegségek etiológiáját, és bizonyítékkal szolgál a részvétel és a halálozás közötti kapcsolatra.

Az elemzések azt mutatják, hogy a magas részvételi hajlandóságú területeken élő férfiak és nők általában idősebbek, dán származásúak voltak, és jobb társadalmi-gazdasági helyzettel rendelkeztek, illetve kisebb arányban szenvedtek súlyos betegségben. A kiegészítő elemzések alapján látható, hogy a társadalmi-gazdasági helyzetben nincs jelentős különbség az intervenciós és kontrollcsoportok tagjai között a magas részvételi hajlandóságú területeken. Hasonlóképpen nem volt nagy eltérés az alacsony és közepes részvételi hajlandóságú területeken sem. A 10 éves követési időszak alatt 592 $(5,2 \%)$ személy halt meg az intervenciós csoportban és 2539 (5,4\%) a kontrollcsoportban. [1. ábra]

1. ábra: Halálozási okok megoszlása az alacsony (a), közepes (b) és magas (c) részvételi hajlandóságú területeken élö férfiak és nők között.

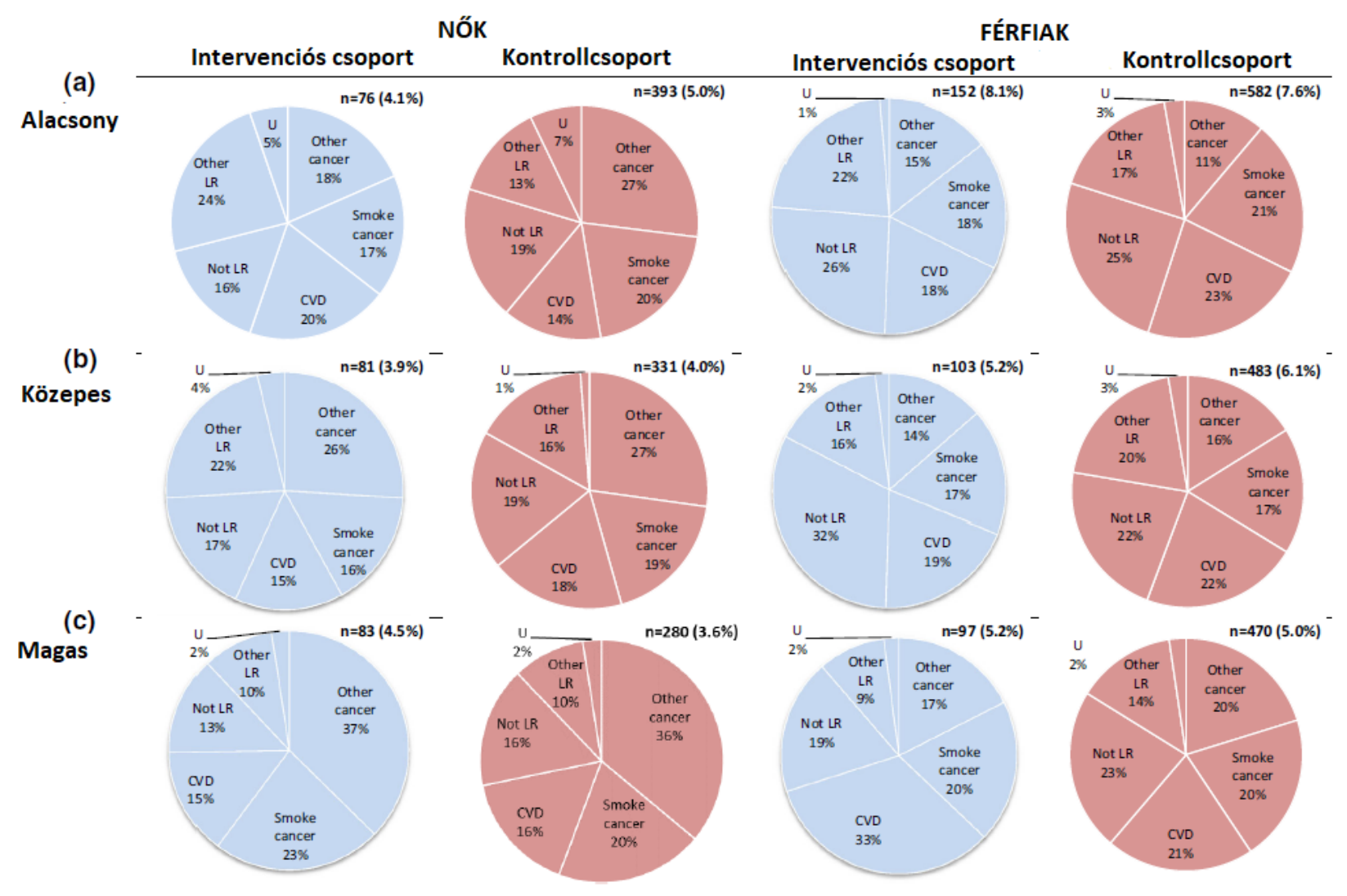

Forrás: Az eredeti ábra magyar szöveggel

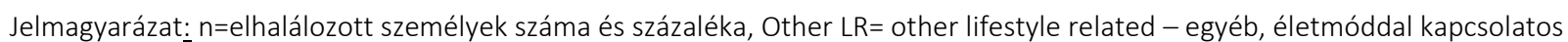
megbetegedés, Not LR= not lifestyle related - nem életmóddal kapcsolatos megbetegedés U=unknown - ismeretlen, other cancer = Egyéb daganatos megbetegedés, Smoke cancer = dohányzással kapcsolatos daganatos megbetegedés, CVD = cardiovascular disease - kardiovaszkuláris megbetegedés. 


\section{KÖVETKEZTETÉSEK}

A fentiek alapján a kutatók úgy vélik, megalapozott okunk van azt hinni, hogy a magasabb halálozási kockázatra vonatkozó eredményeket megmagyarázza az intervenció, azaz életmódbeli beavatkozás negatív hatása. Nincs egyértelmű magyarázat, de három feltételezésük van:

1. A dohányzás mértéke eleve alacsony a magas részvételi hajlandóságú területeken. Azok, akik továbbra is a dohányoznak annak ellenére, hogy olyan környéken laknak, ahol a dohányzásellenesség a norma, valószínúleg nagyon dohányzásfüggók. Amikor a kutatók felhívják a figyelmüket, mennyire fontos a dohányzás abbahagyása, rádöbbenek, hogy erre képtelenek: ez stressz forrása lesz az életükben.

2. Ezzel magyarázható a dohányzás intenzitásának növekedése is. Másrészről a kutatók rámutatnak arra is, hogy a nagyobb megbélyegzés miatt a dohányzók jelentősebb erőfeszítéseket tettek a leszokás irányába, és csökkentették a napi cigarettamennyiségüket.

3. A magas részvételi hajlandóságú területeken a részvétel oka jellemzően egészségtudatos gondolkodásból fakad. A tanulmány szerzői feltételezik, hogy a női dohányosok nem képesek leszokni olyan könnyen a dohányzásról, mint a férfiak, hanem különböző táplálékkiegészítőket vásárolnak. Ez a kutatók szerint nagyon rossz döntés, ugyanis a közhiedelemmel ellentétben, a béta-karotin nem védi meg a dohányosokat a rákbetegségektől, hanem fokozza a dohányzással kapcsolatos daganatos megbetegedések kialakulásának kockázatáti.

4. Pszichológiai oldalról a tanulmány készítői feltételezik, hogy a kutatás közbeni tüdőfunkcióvizsgálatok negatív eredményei csökkentik a női dohányosok hajlandóságát a dohányzás abbahagyására a hamis biztonságérzet miatt.

\section{TANULSÁGOK A HAZAI SZAKEMBEREK SZÁMÁRA}

A tanulmány az intervencióval járó kutatások tervezői számára rendkívüli fontossággal bír. Jóllehet maguk a szerzők fogalmazták meg, hogy következtetéseik inkább feltételezések, az „Inter99” randomizált vizsgálat eredményei megkérdőjelezhetetlenek. Az a paradoxon, hogy az egészségtudatosabb és magas részvételi hajlandóságú területeken élő nők között miért volt magasabb a halálozási arány, még további kutatásokat igényel. Az viszont már biztosan kijelenthető, hogy feltétlenül oda kell figyelni a kutatás folyamata során, hogy a résztvevőket a legkevesebb stressz érje, minél megbízhatóbb forrásból szerezzék be ismereteiket, és folyamatos legyen a kapcsolat a vizsgálói csapattal, hogy a résztvevők a részeredményeket ne értelmezzék félre.

\section{KÖSZÖNETNYILVÁNÍTÁS}

Köszönettel tartozunk a publikálás támogatásáért, amely az EFOP-3.6.1-16-2016-00006 „A kutatási potenciál fejlesztése és bővítése a Neumann János Egyetemen" pályázat keretében valósult meg. A projekt a Magyar Állam és az Európai Unió támogatásával, az Európai Szociális Alap társfinanszírozásával, a Széchenyi 2020 program keretében valósul meg.

\footnotetext{
' Alpha-Tocopherol, Beta Carotene Cancer Prevention Study Group. The effect of vitamin E and beta carotene on the incidence of lung cancer and other cancers in male smokers. N Engl J Med. 1994;330:1029-1035.
} 